\title{
The Effect of Physiological Changes In Pregnant Women's Education on Anxiety Levels
}

\author{
Husnawati $^{1}$, Fitriani $^{2 *}$, Nadia Alfira ${ }^{3}$ \\ ${ }^{1}$ Nursing Student, Stikes Panrita Husada Bulukumba, Indonesia \\ ${ }^{2,3}$ Department of Nursing Stikes Panrita Husada Bulukumba, Indonesia
}

Corresponding author: Fitriani

Email: Fitrianivivi@gmail.com

\begin{abstract}
Health education regarding pregnant women anxiety will provide more understanding to pregnant women as well as to prevent stress. The phenomenon of the problem at Bonto Bangun Puskesmas is that health education is carried out in the class of pregnant women, but not all pregnant women participate in the program. The aim of the study was to determine the effect of physiological change education in pregnant women on the anxiety level of pregnant women at Bonto Bangun Community Health Center. This study used a pre-experimental design by means of One-shot case study. The number of samples is 5 people, sampling technique with purposive sampling. The research was conducted at the Bontobangun Community Health Center in August 2020. The results showed that the level of anxiety of pregnant women before education was the highest moderate anxiety compared to no anxiety, mild and severe anxiety. Meanwhile, the level of anxiety of pregnant women after being given education decreased, namely mild anxiety was higher than moderate anxiety and there was no anxiety. After testing the analysis using SPSS, namely the marginal homogeneity test, the $\mathrm{p}$ value was $0.000<\alpha$ value of 0.05 . This means that there is a significant correlation between the two variables. Conclusions and suggestions: There is an effect of physiological change education of pregnant women on the level of anxiety of pregnant women at Bontobangun Community Health Center. It is hoped that education on physiological changes will become a reference for pregnant women classes or other programs.
\end{abstract}

Keywords: Physiological Change Education, Pregnant Women, Anxiety Level. 


\section{PENDAHULUAN}

Dunia telah kembali merumuskan komitmen global dalam bidang kesehatan untuk 15 tahun ke depan yang diberi nama Sustainable Development Goals (SGDs) yang akan dicapai sampai dengan tahun 2030. SDGs atau tujuan pembangunan berkelanjutan ini hadir menggantikan Millenium Development Goals (MDGs) yang disepakati oleh 198 negara di tahun 2000 (Nurbaiti, 2019). Kehamilan adalah salah satu periode paling penting dalam kehidupan seorang wanita, karena terjadi berbagai perubahan dari aspek fisik, sosial dan psikologis. Ketakutan yang tidak diketahui, stress, masalah-masalah sehari-hari yang berhubungan dengan perubahan hormon sering menyebabkan kecemasan pada ibu hamil. Secara psikologis kehamilan dianggap sebagai krisis emosional. Jika krisis emosional tersebut tidak dikendalikan akan mengakibatkan krisis berkepanjangan dan akan meninggalkan konsekuensi yang tak terhitung untuk ibu dan bayinya (Aisyah et al., 2019).

Organisasi Kesehatan Dunia (WHO) mencatat sebanyak lebih dari 5 juta wanita Indonesia yang melahirkan setiap tahun. WHO memperkirakan bahwa pada tahun 2020 terjadi gangguan kecemasan dan depresi yang akan menjadi penyebab utama beban penyakit global pada wanita selama mereka mengalami reproduksi (Zhang, 2018). Prevalensi kecemasan dan depresi pada negara maju sekitar 7-20\% dan di negara berkembang sekitar lebih dari 20\% (Biaggi et al., 2016). Prevalensi gangguan kecemasan selama kehamilan, di negara-negara maju dan berkembang adalah 10\% dan 25\%.(Aisyah et al., 2019). Skala nasional, berdasarkan hasil penelitian Astuti (2005) dalam Alza (2017) menunujukkan sebesar $46 \%$ ibu yang mengalami kecemasan ringan, 50\% kecemasan sedang dan $4 \%$ kecemasan berat dari $50 \mathrm{ibu}$ hamil. Berdasarkan skala provinsi Sulsel tngka kunjungan ANC K4 ibu hamil sebanyak 60\% (Riskesdas, 2018). Sedangkan di Puskesmas Bonto Bangun sendiri, jumlah pasien ibu hamil yaitu pada tahun 2017 sebanyak 307 orang, tahun 2018 sebanyak 317 orang dan pada tahun 2019 sebayak 401 orang sedangkan tahun 2020 bulan Desember 2019Februari 2020 sebanyak 38 orang. Data ibu hamil dalam kelas ibu hamil yang aktif 15 orang, hanya sekali datang dalam kelas ibu hamil sebanyak 19 orang dan tidak pernah datang sebanyak 4 orang.

Kehamilan adalah periode yang ditandai oleh ambivalensi afektif, ketakutan dan perubahan suasana hati, yang dapat berakibatdalam stres dan kecemasan, dan mempengaruhi kesehatan mental ibu hamil. Mengatasi kecemasan selama kehamilan penting untuk dilakukan karena berhubungan dengan hasil obsetri yang buruk dan masalah perkembangan pada bayi. Selanjutnya, stres dan kecemasan bisa berhubungan dengan depresi nifas, gangguan berat itu 
dapat mempengaruhi tidak hanya kesehatan mental ibu tetapi juga hubungan antara ibu dan anaknya (Cunha et al., 2017). Awal kehamilan, ibu sudah mengalami kegelisahan dan kecemasan. Kegelisahan dan kecemasan selama kehamilan merupakan kejadian yang tidak terelakkan, hampir selalu menyertai kehamilan dan bagian dari suatu proses penyesuaian yang wajar terhadap perubahan fisik dan psikologis yang terjadi selama kehamilan. Perubahan ini terjadi akibat perubahan hormon yang akan mempermudah janin untuk tumbuh dan berkembang saat dilahirkan (Bidjuni and Kallo, 2014). Adapun beberapa perubahan yang terjadi ibu hamil salah satunya yaitu adaptasi fisiologis dan perubahan psikologis. Akibat adanya perubahan fisiologis yang terjadi pada ibu hamil dapat menyebabkan terjadinya risiko komplikasi yang dapat mengancam jiwa ibu. Hal tersebut yang akan menyebabkan terjadinya kasus kematian ibu (Putri and Astutik, 2018).

Dampak yang dapat terjadi pada ibu yang menderita stress dan cemas saat kehamilan adalah akan mengalami lepasnya hormon-hormon stress sehingga menyebabkan gangguan aliran darah yang ada di dalam rahim dan mengakibatkan lemahnya proses persalinan (partus lama), resiko sectio cesarea dan persalinan dengan alat. Dampak resiko yang dapt terjadi pada bayi adalah dapat menyebabkan kelainan bawaan berupa kegagalan akan penutupan celah palatum, prematur, BBLR, kegawatan dan nanti terjadi gangguan prilaku dan emosi anak.

Wanita selama kehamilannya memerlukan waktu untuk beradaptasi dengan berbagai perubahan yang terjadi dalam dirinya. Perubahan yang terjadi selama kehamilan umumnya menimbulkan ketidaknyamanan dan kekhawatiran bagi sebagian besar ibu hamil (Walangadi et al., 2014). Perubahan pada ukuran tubuh, sistem reproduksi, sistem integumen, serta sistem pencernaan secara keseluruhan membuat tubuh ibu hamil tersebut tampak jelek dan tidak percaya diri. Kekhawatiran dan ketakutan ini sebenarnya tidak berdasar, untuk itu ibu hamil memerlukan nasihat dan saran khususnya dari bidan dan dokter yang dapat menjelaskan perubahan yang terjadi selama kehamilan sehingga ibu tidak khawatir dengan perubahan yang dialaminya. Menurut WHO, sekitar $15 \%$ dari seluruh ibu hamil kehamilannya akan bertumbuh dan berkembang menjadi komplikasi yang mengancam jiwa ibu, hal tersebut terjadi dikarenakan ibu tidak memahami perubahan yang terjadi pada tubuhnya selama masa kehamilannya (Intan et al., 2016). Berdasarkan hal tersebut, ibu hamil harus memiliki pengetahuan mengenai perbahan fisiologis selama menjalani proses kehamilan.

Pendidikan kesehatan mengenai kecemasan ibu hamil akan memberikan pemahaman yang lebih pada ibu hamil juga untuk mencegah terjadinya stress. Pendekatan yang teliti selama kehamilan, mampu mengurangi faktor resiko yang ditimbulkan saat kehamilan, 
mengendalikan bila terjadi kecemasan dan mencegah terjadinya stress (Guardino and Dunkel Schetter, 2014).

Penelitian yang dilakukan oleh Aisyah et,al pada tahun 2019 dengan judul penelitian Edukasi dalam paket caring terhadap pengetahuan tentang kecemasan pada ibu hamil, hasil penelitian menunjukkan bahwa ada pengaruh pengetahuan sebelum dan sesudah pemberian edukasi cara mengatasi kecemasan ibu hamil dengan nilai $p$ value sebesar 0,001.

Studi awal didapatkan ibu hamil yang mengalami kecemasan diakibatkan karena mereka belum memahami mengenai perubahan fisiologis pada wanita yang menjalani kehamilan. Studi pada 5 ibu hamil yang melakukan kunjungan, dan 3 orang diantaranya tidak pernah ikut dalam kelas ibu hamil dan mengalami kesulitan buang air besar serta mengalami haemoroid, sedangkan yang 2 orang hanya datang 1 kali ke kelas ibu hamil, mengalami keluhan lebih sering sesak nafas karena janin mulai berkembang dan menekan diafragma. Fenomena masalah di Puskesmas Bonto Bangun adalah pendidikan kesehatan dilakukan di kelas ibu hamil, namun tidak semua ibu hamil mengikuti program tersebut. Kemudian sejauh ini menurut bidan dan hasil evaluasi kelas ibu hamil, pengetahuan ibu hamil mengenai kehamilan secara umum pada ibu hamil yang aktif mengikuti kelas ibu hamil hanya $30 \%$, sedangkan yang tidak aktif pengetahuan mengenai kehamilan hanya 15\%. Sehingga masalah tersebut adalah tingkat pengetahuan berbeda jika ikut kelas ibu hamil dan pengetahuan minim walaupun ikut kelas ibu hamil, berkaitan hal tersebut tingkat intervensi yg diberikan harus intens dan terarah pada tujuan. Menurut koordinator lapangan kelas ibu hamil, edukasi fisiologi kehamilan saat ini masih belum efektif diberikan kepada ibu hamil hanya edukasi mengenai tingkat resiko kesehatan ibu hamil secara umum. Masih banyak diantara ibu hamil yang mengalami kecemasan mengenai keadaan perubahan fisiologis yang dialami. Berdasarkan hasil penelitian dan studi awal yang telah dilakukan, menggambarkan bahwa dengan pengetahuan yang baik mengenai perubahan fisiologis pada tubuh selama hamil akan menghasilkan pemikiran positif sehingga dapat menurunkan dan mengatasi kecemasan. Berdasarkan penjelasan tesebut maka peneliti tertarik melakukan penelitian dengan judul Pengaruh edukasi perubahan fisiologis ibu hamil terhadap tingkat kecemasan ibu hamil di Puskesmas Bonto Bangun.

\section{METODE PENELITIAN}

Penelitian ini menggunakan rancangan Pra-eksperimental dengan cara One-shot case Study yaitu dengan menggunakan intervensi / tindakan pada satu kelompok kemudian diobservasi pada variabel dependen setelah dilakukan intervensi (Nursalam, 2009). Penelitian 
dilaksanakan pada bulan Juli-Agustus 2020 di Wilayah Kerja Puskesmas Bontobangun. Populasi pada penelitian ini adalah semua pasien ibu hamil. Besar sampel yang akan diteliti berdasarkan tehnik pengambilan subjek penelitian. Adapun penentuan sampel pada penelitian ini menggunakan rumus Sopiyudin Dahlan (2009) yakni sebanyak 35 orang. Cara penarikan sampel yang dilakukan pada penelitian ini adalah dengan menggunakan Purposive Sampling yaitu suatu cara pengambilan sampel untuk tujuan tertentu dan sampai mencukupi (Hidayat, 2009). Instrumen penelitian yang digunakan adalah kuesioner baku Hamilton rate scale for anxiety (HRS-A) sebanyak 14 poin menggunakan skala likert yaitu Tidak ada bobot 0 , Ringan bobot 1, Sedang bobot 2, Berat bobot 3, dan Berat sekali bobot 4. Kuesioner yang digunakan untuk pre test dan post test adalah sama. Untuk penentuan tingkat kecemasan, peneliti telah memodifikasi sesuai dengan penelitian-penelitian terdahulu.

Sedangkan untuk instrumen yang digunakan pada saat melakukan edukasi pada responden adalah berupa booklet tentang kehamilan yang tersedia di ruang KIA, peneliti juga menggunakan flipchart. Isi daripada Flipchart adalah menyangkut perubahan fisiologis pada ibu hamil, dampak nya pada ibu hamil akibat perubahan fisiologis dan cara menangani secara mandiri oleh ibu hamil atau bantuan orang lain / tenaga kesehatan.

\section{HASIL}

Berdasarkan tabel 1 dapat diketahui bahwa dari 35 responden di Puskesmas Bontobangun terdapat jumlah responden berdasarkan tingkat kecemasan sebelum edukasi yakni kecemasan sedang sebanyak 21 orang $(60.0 \%)$, kecemasan berat sebanyak 9 orang (25.7\%), kecemasan ringan sebanyak 3 orang (8.6\%) dan tidak ada kecemasan sebanyak 2 orang (5.7\%).

Tabel 1. Distribusi Frekuensi Responden Berdasarkan Tingkat Kecemasan Sebelum Edukasi

\begin{tabular}{ccc}
\hline Tingkat Kecemasan Sebelum Edukasi & Frekuensi (f) & Persentase (\%) \\
\hline Tidak Cemas & 2 & 5.7 \\
Kecemasan Ringan & 3 & 8.6 \\
Kecemasan Sedang & 21 & 60.0 \\
Kecemasan Berat & 9 & 25.7 \\
Total & $\mathbf{3 5}$ & $\mathbf{1 0 0}$ \\
\hline
\end{tabular}

Berdasarkan tabel 2 dapat diketahui bahwa dari 35 responden di Puskesmas Bontobangun terdapat jumlah responden berdasarkan tingkat kecemasan setelah edukasi yakni tidak cemas sebanyak 5 orang (14.\%), kecemasan ringan sebanyak 21 orang (60.0\%), dan kecemasan sedang sebanyak 9 orang (25.7\%). Sedangkan kecemasan berat tidak ada. 
Tabel 2. Distribusi Frekuensi Responden Berdasarkan Tingkat Kecemasan Setelah Edukasi

\begin{tabular}{ccc}
\hline Tingkat Kecemasan Sebelum Edukasi & Frekuensi (f) & Persentase (\%) \\
\hline Tidak Cemas & 5 & 14.3 \\
Kecemaan Ringan & 21 & 60.0 \\
Kecemasan Sedang & 9 & 25.7 \\
Kecemasan Berat & 0 & 0 \\
\hline Total & $\mathbf{3 5}$ & $\mathbf{1 0 0}$ \\
\hline
\end{tabular}

Berdasarkan tabel 3 dapat dilihat bahwa dari 35 responden, bahwa tingkat kecemasan ibu hamil terkait perubahn fisiologi sebelum edukasi dapat kita lihat bahwa masih terdapat kecemasan ringan, sedang, dan berat serta ada yang tidak mengalami cemas, setelah edukasi maka didapatkan tingkat kecemasan yakni tidak ada kecemasan, kecemasan ringan, dan kecemasan sedang. Dengan hasil penelitian diatas dapat kita ketahui pada sebagian besar yakni sebelum edukasi didapatkan kecemasan sedang sebanyak 21 orang, setelah dilakukan edukasi maka didapatkan kecemasan ringan sebanyak 21 orang, artinya terjadi perubahan tingkat kecemasan ibu hamil setelah dilakukan intervensi. Hasil uji Marginal Homogeneity didapatkan nilai $p=0.000(<\alpha=0.05)$ yang artinya ada pengaruh edukasi perubahan fisiologi ibu hamil terhadap tingkat kecemasan ibu hamil.

\section{Tabel 3. Pengaruh Edukasi Perubahan Fisiologi Ibu Hamil Terhadap Tingkat Kecemasan Ibu} Hamil

\begin{tabular}{|c|c|c|c|c|c|c|c|c|c|c|c|}
\hline \multirow{3}{*}{$\begin{array}{c}\text { Tingkat } \\
\text { Kecemasan } \\
\text { Sebelum } \\
\text { Edukasi } \\
\end{array}$} & \multicolumn{10}{|c|}{ Tingkat Kecemasan Setelah Edukasi } & \multirow{3}{*}{$\begin{array}{c}P \\
\text { value }\end{array}$} \\
\hline & \multicolumn{2}{|c|}{$\begin{array}{l}\text { Tidak } \\
\text { Cemas }\end{array}$} & \multicolumn{2}{|c|}{$\begin{array}{c}\text { Kecemasan } \\
\text { Ringan }\end{array}$} & \multicolumn{2}{|c|}{$\begin{array}{l}\text { Kecemasan } \\
\text { Sedang }\end{array}$} & \multicolumn{2}{|c|}{$\begin{array}{c}\text { Kecemasan } \\
\text { Berat }\end{array}$} & \multicolumn{2}{|c|}{ Total } & \\
\hline & $\mathrm{f}$ & $\%$ & $\mathrm{f}$ & $\%$ & $\mathrm{f}$ & $\%$ & $\mathrm{f}$ & $\%$ & $\mathrm{f}$ & $\%$ & \\
\hline Tidak cemas & 2 & 5,7 & 0 & 0 & 0 & 0 & 0 & 0 & 2 & 5,7 & \\
\hline $\begin{array}{l}\text { Kecemasan } \\
\text { ringan }\end{array}$ & 3 & 8,6 & 0 & 0 & 0 & 0 & 0 & 0 & 3 & 8,6 & 0,00 \\
\hline $\begin{array}{l}\text { Kecemasan } \\
\text { Sedang }\end{array}$ & 0 & 0 & 21 & 60 & 0 & 0 & 0 & 0 & 21 & 60 & \\
\hline Kecemasan Berat & 0 & 0 & 0 & 0 & 9 & 25,7 & 0 & 0 & 9 & 25,7 & \\
\hline Total & 5 & 14,3 & 21 & 60 & 9 & 25,7 & $\mathbf{0}$ & $\mathbf{0}$ & 35 & 100 & \\
\hline
\end{tabular}

\section{PEMBAHASAN}

Kecemasan dalam kehamilan dapat berhubungan dengan kekhawatiran ibu hamil tentang kesehatan mereka, kesehatan bayi, dan persalinan (Kane et al., 2014). Selain itu, stres dan kecemasan dapat berhubungan dengan depresi postpartum dikemudian hari, gangguan yang parah dapat Mempengaruhi tidak hanya kesehatan mental ibu juga tapi hubungan antara ibu dan anaknya (Polanska et al., 2017).

Berdasarkan dengan penelitian yang dilakukan oleh Widorini (2017) dengan judul penelitian pengaruh penyuluhan tentang menopause terhadap tingkat kecemasan pada 
ibu menopause dalam menghadapi menopause di Kelurahan Oro-Oro Dowo Kota Malang. Hasil penelitian yakni pada sekelompok ibu menunjukkan bahwa sebagian besar tingkat kecemasan sebelum penyuluhan (pre test) adalah kecemasan ringan, yaitu sejumlah 18 orang (58.1\%). Sedangkan pada penelitian Esthini (2016) dengan judul pengaruh kelas ibu hamil terhadap kecemasan ibu primigravida di Puskesmas Wates Kabupaten Kulon Progo dilakukan pada sekelompok ibu hamil diperoleh nilai pre-test, terbanyak pada tingkat kecemasan sedang yaitu $33(97.06 \%)$ dengan nilai rata-rata 49.12 yang berarti dalam tingkat kecemasan sedang. Sedangkan kecemasan berat dan kecemasan ringan memiliki nilai yang rendah sehingga ibu hamil dalam kecemasan ambang sedang.

Menurut asumsi peneliti bahwa tingkat kecemasan ibu hamil sebelum dilakukan edukasi menggambarkan tingkat kecemasan sedang sampai berat, hal tersebut disebabkan karena kurangnya pengetahuan ibu hamil yang dapat berpengaruh pada kesiapan fisik seorang ibu hamil dalam masa kehamilan. Kurangnya pengetahuan tentang persalinan akan menimbulkan perasaan cemas.

Berdasarkan dengan penelitian yang dilakukan oleh Widorini (2017) dengan judul penelitian pengaruh penyuluhan tentang menopause terhadap tingkat kecemasan pada ibu menopause dalam menghadapi menopause di Kelurahan Oro-Oro Dowo Kota Malang pada sekelompok ibu menunjukkan bahwa sebagian besar tingkat kecemasan setelah penyuluhan (post test) adalah tidak ada kecemasan, yaitu sejumlah 18 orang (58.1\%). Sedangkan pada penelitian Esthini (2016) dengan judul pengaruh kelas ibu hamil terhadap kecemasan ibu primigravida di Puskesmas Wates Kabupaten Kulon Progo dilakukan pada sekelompok ibu hamil diperoleh nilai post-test, terbanyak pada tingkat kecemasan rendah $31(91,18 \%)$ dengan nilai rata-rata 38,12 yang berarti dalam tingkat kecemasan ringan. Artinya terdapat perbedaan tingkat kecemasan ibu hamil sebelum dilakukan intervensi dan setelah dilakukan intervensi.

Peneliti berasumasi bahwa edukasi yang diperoleh ibu hamil dari pendidikan kesehatan akan disimpan dalam sistem memori mereka untuk diolah dan diberikan makna yang selanjutnya informasi tersebut akan digunakan pada saat diperlukan. Sehingga tingkat kecemasan dapat berubah kearah positif atau lebih rendah dari sebelumnya.

Kecemasan merupakan salah satu gangguan emosional yang sering dialami ibu hamil, terutama pada primigravida. Salah satu program pemerintah dalam upaya peningkatan kesehatan pada ibu hamil adalah dengan mengadakan kelas ibu hamil. Faktor-faktor yang mempengaruhi kecemasan pada ibu hamil diantaranya adalah kurangnya informasi mengenai penyakit, dukungan keluarga, kecukupan keuangan, stres dari lingkungan, frekuensi mual dan 
muntah yang tinggi (faktor kesehatan fisik ibu hamil), sikap terhadap kehamilan dan kemampuan penguasaan kehamilan, proses penyesuaian diri terhadap kehamilan baik secara fisik maupun psikososial, serta informasi tentang pengalaman persalinan yang menakutkan (Andriana, 2011).

Penelitian ini sejalan dengan penelitian yang dilakukan oleh Aisyah (2019) dengan judul penelitian edukasi dalam paket Caring terhadap pengetahuan tentang kecemasan pada ibu hamil didapatkan bahwa rata-rata pengetahuan responden sebelum edukasi adalah 10,52 dan rata-rata tingkat kpengetahuan responden sesudah pemberian edukasi adalah 12,53. Terlihat kenaikan yang signifikan nilai rata-rata pengetahuan pada responden sebelum dan sesudah edukasi sebesar 2,013. Dari hasil uji statistik didapatkan nilai $\mathrm{p}=0,001(<0,05)$ dengan confidence interval $95 \%$ dapat disimpulkan bahwa ada perbedaan yang sangat signifikan antara pengetahuan responden sebelum dan sesudah edukasi dalam pemberian paket Caring untuk kecemasan ibu hamil.

Hal ini sejalan pula dengan penelitian Esthini (2016) dengan judul penelitian pengaruh kelas ibu hamil terhadap kecemasan ibu primigravida di Puskesmas Wates Kabupaten Kulon Progo Tahun 2016. Hasil penelitian yaitu rata-rata skor kecemasan pre-test pada kelompok eksperimen $(49,12 \%)$ lebih tinggi daripada kelompok kontrol. Rata-rata skor kecemasan posttest pada kelompok eksperimen $(38,12 \%)$ lebih rendah dari pada kelompok kontrol. Secara statistik bila dilihat perbedaan rata-rata sebesar $(-9,294)$ atau $p=0.0001$ yaitu kurang dari 0,05 yang artinya terdapat perbedaan yang bermakna tingkat kecemasan antara kelompok eksperimen dan kelompok kontrol.

Hasil penelitian didukung oleh teori yang mengatakan bahwa pendidikan kesehatan bermanfaat dalam meningkatkan pengetahuan, dan kepercayaan diri ibu hamil yang diharapkan dapat menurunkan kecemasan (Gayathri, 2010 dalam Widorini, 2017).

Peneliti berasumsi bahwa edukasi yang diberikan kepada ibu hamil dapat membuktikan perbedaan tingkat kecemasan sebelum edukasi dan setelah edukasi sehingga pemberian edukasi kepada ibu hamil terkait perubahan fisiologi sangat membantu ibu hamil dalam menurunkan kecemasan mengenai keadaan perubahan yang dirasakan oleh ibu hamil. Sehingga untuk mengurangi rasa cemas perlu tenaga kesehatan melakukan pemberian informasi kepada ibu hamil melalui edukasi / penyuluhann oleh karena itu kedepannya pada program ibu hamil harus selalu ada edukasi mengenai keadaan ibu hamil. 


\section{KESIMPULAN}

Ada pengaruh edukasi perubahan fisiologi ibu hamil terhadap tingkat kecemasan ibu hamil di Puskesmas Bontobangun dengan hasil uji analisis Marginal Homogeneity didapatkan nilai $p=0.000(<\alpha=0.05)$. Diharapkan hasil penelitian ini meberikan dampak terhadap ibu hamil dengan adanya edukasi mampu menurunkan tingkat kecemasan bagi ibu hamil, sehingga tidak menimbulkan komplikasi ketika menghadapi persalinannya.

\section{DAFTAR PUSTAKA}

Aisyah, R. D., Suparni, S. \& Fitriyani, F. 2019a. Edukasi Dalam Paket Caring Terhadap Pengetahuan Tentang Kecemasan Pada Ibu Hamil. Proceeding of The URECOL, 346349.

Aisyah, R. D., Suparni, S. \& Fitriyani, F. 2019b. Paket Caring Untuk Kecemasan Ibu Hamil. Siklus: Journal Research Midwifery Politeknik Tegal, 8, 15-20.

Andriana, E.2011.Melahirkan Tanpa Rasa Sakit Dengan Metode Relaksasi HypnoBirthing.Jakarta: PT Bhuana Ilmu Populer.

Alza, N. \& Ismarwati, I. 2017. Faktor-faktor yang mempengaruhi kecemasan ibu hamil trimester III. Jurnal Kebidanan dan Keperawatan Aisyiyah, 13, 1-6.

Biaggi, A., Conroy, S., Pawlby, S. \& Pariante, C. M. 2016. Identifying the women at risk of antenatal anxiety and depression: a systematic review. Journal of affective disorders, 191, 62-77.

Bidjuni, H. \& Kallo, V. 2014. Hubungan karakteristik ibu hamil trimester III dengan tingkat kecemasan dalam menghadapi persalinan di Poli KIA Puskesmas Tuminting. Jurnal Keperawatan, 2.

Cunha, A. D., Akerman, L., Rocha, A., Rezende, K. D. C., Junior, J. \& Bornia, R. 2017. Stress and anxiety in pregnant women from a screening program for maternal-fetal risks. Journal of Gynecology \& Obstetrics, 1, 10-13.

Dahlan, Sopiyuddin, 2009. Besar Sampel Dan Cara Pengambilan Sampel Dalam Penelitian Kedokteran Dan Kesehatan. Edisi 2. Jakarta: Salemba Medika

Esthini, Dewi, 2016. Pengaruh Kelas Ibu Hamil terhadap Kecemasan Ibu Primigravida di Puskesmas Wates Kabupaten Kulon Progo Tahun 2016. Skripsi.

Guardino, C. M. \& Dunkel Schetter, C. 2014. Coping during pregnancy: a systematic review and recommendations. Health psychology review, 8, 70-94.

Hidayat, A. A. (ed.) 2010. Metodologi Penelitian Keperawatan dan Kesehatan, Jakarta: Salemba Medika. 
Intan, N., Restuastuti, T. \& Pangaribuan, E. R. 2016. Gambaran Pengetahuan dan Sikap Ibu Hamil Primigravida terhadap Perubahan Fisiologis Tubuh yang Terjadi Selama Masa Kehamilan di Wilayah Kerja Puskesmas Rejosari Pekanbaru. Riau University.

Nurbaiti, N. 2019. Edukasi Kesehatan Prenatal Yoga Pada Ibu Hamil Trimester III Di Puskesmas Putri Ayu Kota Jambi. Jurnal Abdimas Kesehatan (JAK), 1, 206-209.

Nursalam, 2009. Konsep dan Penerapan Metodologi Penelitian Ilmu Keperawatan. Jakarta : Salemba Medika

Kane, H. S., Schetter, C. D., Glynn, L. M., Hobel, C. J. \& Sandman, C. A. 2014. Pregnancy anxiety and prenatal cortisol trajectories. Biological psychology, 100, 13-19.

Polanska, K., Krol, A., Merecz-Kot, D., Jurewicz, J., Makowiec-Dabrowska, T., Chiarotti, F., Calamandrei, G. \& Hanke, W. 2017. Maternal stress during pregnancy and neurodevelopmental outcomes of children during the first 2 years of life. Journal of paediatrics and child health, 53, 263-270.

Putri, B. A. G. \& Astutik, T. 2018. Pengaruh Kelas Ibu Hamil Terhadap Peningkatan Pengetahuan Tentang Antenatal Care Pada Ibu Hamil Dengan Menggunakan Pendekatan Model Community As Partner Di Dusun Karangasem Desa Glagahwero Kecamatan Panti Kabupaten Jember. The Indonesian Journal of Health Science, 145149.

Riskesdas, 2018. Laporan hasil riset kesehatan dasar (RISKESDAS) Indonesia 2018. Jakarta : Badan Penelitian Dan Pengembangan Kesehatan Dasar

Zhang, Y., Muyiduli, X., Wang, S., Jiang, W., Wu, J., LI, M., Mo, M., Jiang, S., Wang, Z., Shao, B., Shen, Y. \& Yu, Y. 2018. Prevalence and relevant factors of anxiety and depression among pregnant women in a cohort study from south-east China. JOURNAL OF REPRODUCTIVE AND INFANT PSYCHOLOGY. https://doi.org/10.1080/02646838.2018.1492098

Walangadi, N. N., Kundre, R. \& Silolonga, W. 2014. Hubungan Pengetahuan Ibu Hamil Primigravida Trimester III Dengan Tingkat Kecemasan Ibu Menghadapi Persalinandi Poli Kia Puskesmas Tuminting. Jurnal Keperawatan, 2.

Widorini, Devi Ertha, 2016. Pengaruh Penyuluhan tentang Menopause terhadap Tingkat Kecemasan pada Ibu Menopause dalam Menghadapi Menopause di Kelurahan Oro-Oro Dowo Kota Malang. Jurnal Ilmu Kesehatan Vol. 6 No. 1, Nopember 2017 